\title{
0726. The effects of carnitine on renal tissue damage and metabolic alteration among the rat intraabdominal sepsis model
}

\author{
S Cetin ${ }^{*}$, S Deniz, A Sezer, H Sen, S Ozkan \\ From ESICM LIVES 2014 \\ Barcelona, Spain. 27 September - 1 October 2014
}

\section{Introduction}

Sepsis is a systematic inflammatory reaction that causes renal damage frequently. Carnitine is considered as an essential mediator of metabolic pathway during sepsis and critical conditions. It has an important role in facilitating medium- and long-chain fatty acid transport from the cytosol into mitochondria for $\beta$-oxidation and energy generation [1].

\section{Objectives}

We investigated the effects of carnitine usage on renal tissue damage and metabolic changes on rats with sepsis model. We hypothesized that carnitine decreases systemic inflammation and renal tissue damage.

\section{Methods}

21 male rats randomly divided into 3 groups: sham operated $(\mathrm{SO} ; \mathrm{n}=7)$, sepsis $(\mathrm{S} ; \mathrm{n}=7)$ and sepsis + carnitine $(\mathrm{S}+\mathrm{C} ; \mathrm{n}=7)$. In $\mathrm{SO}$ group only laparatomy was performed. In $\mathrm{S}$ and $\mathrm{S}+\mathrm{C}$ groups caecal ligation and puncture was performed. At the postoperative $6^{\text {th }}, 30^{\text {th }}$ and $54^{\text {th }}$ hours $1 \mathrm{ml}$ saline was administered intraperitoneally to both PO and S groups. Similarly $100 \mathrm{mg} / \mathrm{kg}$ carnitine was administered intraperitoneally to $\mathrm{S}+\mathrm{C}$ group at the postoperative $6^{\text {th }}, 30^{\text {th }}$ and $54^{\text {th }}$ hours. After gathering blood and renal tissue samples, all rats were sacrificed at 60 hours postoperatively. Tissue malondialdehyde (MDA) levels were measured for oxidative stress and inflammation. Serum cytokines (TNF- $\alpha$, IL-1, IL-6 and IL-10), neutrophil gelatinase-associated lipocalin (NGAL) and anti-caspase 3 were measured for inflammation markers, renal tissue damage and renal apoptosis, respectively.

Gulhane Military Medical Academy, Haydarpasa Training Hospital, Department of Anesthesiology and Reanimation, Istanbul, Turkey

\section{Results}

In histopathological examination, $\mathrm{S}+\mathrm{C}$ group has achieved better results in mononuclear cell infiltration score than the $\mathrm{S}$ group. Also, the increase in TNF- $\alpha$, IL-1, IL- 6 , MDA, NGAL and anti-caspase 3 levels in $\mathrm{S}+\mathrm{C}$ group were found to be lower than those of $S$ group.

\section{Conclusion}

Using carnitine in sepsis decreases the serum cytokine levels and renal damage and apoptosis via supressing the oxidative stress and inflammation both in blood and tissue.

Published: 26 September 2014

\section{Reference}

1. Hatamkhani $S$, et al: Carnitine and sepsis: a review of an old clinical dilemma. J Pharm Pharm Sci 2013, 16(3):414-23.

doi:10.1186/2197-425X-2-S1-P48

Cite this article as: Cetin et al:: 0726 . The effects of carnitine on renal tissue damage and metabolic alteration among the rat intraabdominal sepsis model. Intensive Care Medicine Experimental 2014 2(Suppl 1):P48.

Submit your manuscript to a SpringerOpen ${ }^{\odot}$ journal and benefit from:

- Convenient online submission

- Rigorous peer review

- Immediate publication on acceptance

- Open access: articles freely available online

- High visibility within the field

- Retaining the copyright to your article

Submit your next manuscript at $>$ springeropen.com

\section{SpringerOpen ${ }^{\circ}$}

C 2014 Cetin et al; licensee Springer. This is an Open Access article distributed under the terms of the Creative Commons Attribution License (http://creativecommons.org/licenses/by/2.0), which permits unrestricted use, distribution, and reproduction in any medium, provided the original work is properly cited. 